\title{
Difficulties in Solving Non-Routine Problems: Preliminary Analysis and Results
}

\author{
Muslimah Shawan ${ }^{1 *}$, Sharifah Osman² and Mohd Salleh $\mathrm{Abu}^{2}$ \\ ${ }^{1}$ Sekolah Menengah Sains Batu Pahat, Johor, Malaysia \\ ${ }^{2}$ School of Education, Faculty of Social Sciences and Humanities, Universiti Teknologi Malaysia
}

\begin{abstract}
Students have been taught to solve problems since primary school. However, they still have been having difficulties in solving mathematics problems, especially non-routine problems. By searching errors in mathematics skills and cognitive abilities that have been causing difficulties in solving nonroutine problems, this study aims to determine the dominant difficulties that high-achieving students commonly face. A problem-solving test (PST) that comprises four non-routine problems involving algebra was distributed to 56 Form Four selected students through purposive sampling. Each problem is followed by a reflection that allows students to describe the difficulties they face while solving the problem. Hence, the qualitative and quantitative analysis of answer scripts as well as students' reflection shows that the dominant difficulties faced by high-achieving students when solving non-routine problems are language and information management skills. Poor mastery of these two skills has resulted in students being unable to decipher the problem accordingly which then leads to failing to solve the problems. The findings of this study provide important insight for educators and also researchers in assisting students to deal with their difficulties to solve nonroutine problems.
\end{abstract}

Keywords: algebra; difficulties; mathematics; non-routine problems; problem-solving

\section{INTRODUCTION}

According to the National Council of Teachers of Mathematics (NCTM), problem-solving abilities are one of the most critical skills with which mathematical knowledge and skills are used at the highest level (F. Lester \& Cai, 2015). There are two types of problems observed in literature: routine problems and non-routine problems (Arslan \& Altun, 2007). Routine problems can be solved by approaches, strategies, formulas, or known formulas (Polya, 2004) that help to establish a connection between mathematical knowledge and real-life (Xin et al., 2007). While non-routine problems involve many processes and require higher-order thinking skills (HOTs). After mastering the basic concepts and solutions of the routine problems (Schoenfeld, 1992b), only then HOTS can be acquired. Countries that perform well in international mathematics assessments like TIMSS (Trends in International Mathematics and Science Study) and PISA (Program for International Student Assessment) devote more time to non-routine problems (Arslan \& Yazgan, 2015)

Non-routine problems are viewed as ill-defined problems (Brunning et al., 1999), and there is no predictable approach to deal with them. Non-routine problems are problems that replicate real-life situations and do not provide keywords to solve using known procedures or standard methods (Arslan \& Altun, 2007) but, using some unique strategies, may provide some possible acceptable solutions (Brunning et al., 1999). Finding solutions to non-routine problems requires the development of techniques and challenges one to think to understand the concepts involved (Jacinta et al., 2017). In general, non-routine problems can develop problem-solving skills and develop those skills for use when dealing with reallife problems (Polya, 1957; Schoenfeld, 1992a). As nonroutine problems require a combination of several problemsolving strategies to be used, therefore, they need to be

*Corresponding author's e-mail: muslimahshawan@gmail.com 
included in learning mathematics to develop critical and creative thinking (Mabilangan et. al., 2011; Polya, 1981).

A non-routine problem-solving process is not a straightforward process as it requires creative thinking to apply some strategies in understanding and finding the best way to solve them. Students need to have a strong mathematical knowledge base, sufficient experience in learning how to solve problems, knowledge of various mathematical models or representations, and the ability to model or represent situations mathematically by constructing or drawing conclusions to succeed in solving non-routine problems (F. K. Lester, 2013). However, a study by Arslan \& Altun (2007) and Yazgan et al. (2012) found that students lacked the skills and lack of confidence to choose and use strategies to solve problems and then encountered difficulties in solving non-routine problems. According to Schoenfeld (1992a), difficulties in solving non-routine problems may be due to students' failure to learn and apply some heuristics, such as making diagrams or using simpler cases.

Although many students struggle with problem-solving (Garderen, 2006; Tarzimah \& Thamby Subahan, 2010), they still need to learn mathematics especially algebra because of its importance in everyday life. The primary and secondary mathematics curriculum emphasises the skills of arithmetic, communication, construction, and technology application skills (Curriculum Development Division, 2015, 2016; Ministry of Education, 2013), which are important to apply in problem-solving. Deficiencies in any of these skills can lead to difficulties in mathematics skills among students. The main reason for this difficulty is because solving non-routine problems requires a lot of skills to be used together (Roy, 2014).

In Malaysia, some evidence show students had difficulty in mathematics. These include difficulty in understanding and retrieving concepts, formulas, facts, and procedure and having trouble visualising mathematics problems and concepts (Abd Wahab et. al., 2016; Tarzimah \& Thamby Subahan, 2010). Difficulties in solving problems are due to weakness in understanding concepts, logical thinking, and strategic knowledge. However, not many studies emphasise the difficulty of solving non-routine problems related to the mathematics skills deficit. If the difficulties in the mathematics skills involved are understood, the teacher can organise a better program for solving the issues. Also, if the learning approach and teaching strategies used do not meet students intellectual needs, students' difficulty in learning mathematics will worsen. Therefore, Meese (2001) argues that when teachers understand the problems and difficulties of learning and their students' potential, effective teaching and learning strategies can be implemented to minimise the difficulties experienced by students.

Lack of mathematical skills leads to difficulties in solving problems (Tarzimah \& Thamby Subahan, 2010). Garderen (2006) adds that deficiencies in visual-spatial skills may lead to difficulties in differentiating, relating, and managing information meaningfully. During the decisionmaking and problem-solving process, students need to apply and integrate several mathematical concepts and skills.

Difficulties in understanding problems may be due to incomplete mastery of number facts, weaknesses in computation, difficulty in making meaningful connections between information, inability to convert information mathematically, incomplete understanding of mathematical language and terms, difficulty in understanding, and visualising concepts mathematically. Also, interpreting and manipulating information effectively in working memory requires language and visual-spatial skills (Garderen, 2006). Any obstacle on any level can lead to difficulties in the problem-solving process. Early understanding and identification of difficulties are important for any intervention (Tarzimah \& Thamby Subahan, 2010). These weaknesses can lead to many mistakes and misunderstandings in the problem-solving process.

Knowledge of procedures and conceptual understanding are essential to problem-solving. However, these skills should be supported by cognitive systems that control the focus and intervention of information processing (Geary, 2004). The ability to use cognitive abilities in problem-solving is crucial. However, many students are using these cognitive abilities ineffectively. Tarzimah \& Thamby Subahan (2010) reported that their students have difficulty in making accurate perceptions and interpretations, taking facts, giving conclusions, and using their logical thinking. Errors in the comprehension of the text, the inability to create a suitable mathematical model and errors in the solution phase may 
cause difficulties in problem-solving. Abdul Halim et al. (2015) shares some students' errors in solving HOTS problems. Newton analysis was used in their study to assess comprehension errors, transformation errors, process skills errors, and encoding errors.

Based on the above discussion, this study aims to determine the dominant difficulties that students face while solving non-routine problems. To better understand the difficulty of problem-solving, it is important to understand the process of its solution. The four-phase problem-solving process consists of; i) understanding the problem, ii) planning strategies, iii) performing the plan, and iv) looking back (Polya, 1957) used in this study. Each phase involves a combination of different mathematics skills and cognitive abilities.

\section{MATERIALS AND METHOD}

This study is a descriptive study that used a quantitative and qualitative approach. Data was obtained through answer scripts of the problem-solving test (PST) to identify the weaknesses and errors that students made. Then, student's reflections and their answer scripts were used to gain a better understanding of how the errors led to difficulties in nonroutine problem-solving. The targeted participants of this study were 56 Form 4 students studying in a fully residential school in Johor. The students were 15 to 16 years old. The Malaysian Examinations Board recognises upper secondary students who obtain a minimum score of $70 \%$ in mathematics examinations as high-achieving students in mathematics (Ministry of Education, 2016). Since the entire country complied with this assessment system, this feature was taken into account for classroom selection in this study.

\section{A. Instruments}

The first instrument used in this study was a set of test questions to identify errors made by students while reaching for a solution. The test has four non -routine problems that allow students to apply the math skills they have learned in school to solve those problems. Test items are mathematical problems adapted from previous research but with modifications. Two experts, consisting of mathematics teachers with more than 10 years of experience reviewed each item. They agreed on the selection of items and their suitability for assessing students 'abilities in non-routine problem solving.

Table 1. The Non-Routine Problems

\begin{tabular}{cc}
\hline Problem & Skills \\
\hline 1 & Language Skills - Text Difficulties \\
2 & Arithmetic Skills - Puzzle \\
3 & Information Management Skills - Test Score \\
4 & Algebraic Skills and Arithmetic Skills \\
\hline
\end{tabular}

Since many different approaches and strategies can be used to solve non-routine problems, students should find and apply strategies that they think can solve the problem either using an algebraic or non-algebraic approach. Students are also encouraged to provide draft and alternative solutions that they think can lead to appropriate solutions. Table 1 shows the skills evaluated in each problem used in this study. Problem 1 requires students to determine the number of each banknote owned by the cashier when the value of the money is known. Problem 2 is a puzzle question involving numbers in a pyramid that has an infinite solution. Problem 3 requires students to give the number of correct answers that someone must give to pass a test. While problem 4 requires students to solve problems involving three unknown numbers to find outdoor access code. Although not stated in the question directly, all these problems can be solved using an algebraic approach. Each problem in PST is followed by student's reflection to enable them to express what they feel and explain the difficulties encountered while solving the problem.

\section{B. Procedure}

After obtaining permission from the Education Policy Planning and Research Division (EPRD), the State Education Department (JPN) and the school administration, the test was implemented. The students were given 60 minutes to finish all the problems individually. After they finished answering, the answer scripts were collected for review. Students' reflection is also examined to understand what they think about and the difficulties faced by them.

\section{Data Analysis and Scoring}

In solving non-routine problems, how the results achieved, the strategies used, and the logical thinking on the solutions 
are more important aspects of attention than just reaching the right answers (Hegarty et al., 1995).

Table 2. Rubric of Scoring

\begin{tabular}{|c|c|c|c|}
\hline Process & $\begin{array}{l}\text { Full } \\
\text { Score }\end{array}$ & $\begin{array}{l}\text { Sub- } \\
\text { score }\end{array}$ & Description \\
\hline \multirow[t]{6}{*}{$\begin{array}{l}\text { Understanding } \\
\text { the Problem }\end{array}$} & \multirow{6}{*}{3} & 1 & $\begin{array}{l}\text { Mark important } \\
\text { information on a } \\
\text { problem or move } \\
\text { important information } \\
\text { on the answer space }\end{array}$ \\
\hline & & $\mathrm{o}$ & $\begin{array}{c}\text { There are no marks or } \\
\text { lines on important } \\
\text { information. }\end{array}$ \\
\hline & & 1 & $\begin{array}{c}\text { Represent variables } \\
\text { with appropriate } \\
\text { notation }\end{array}$ \\
\hline & & o & $\begin{array}{c}\text { No notation or misuse } \\
\text { of notation }\end{array}$ \\
\hline & & 1 & $\begin{array}{c}\text { Formulate problem } \\
\text { situations with } \\
\text { mathematical sentences } \\
\text { correctly }\end{array}$ \\
\hline & & o & $\begin{array}{l}\text { No response or use of } \\
\text { wrong mathematical } \\
\text { sentences }\end{array}$ \\
\hline \multirow[t]{4}{*}{$\begin{array}{l}\text { Planning } \\
\text { Strategies }\end{array}$} & \multirow{4}{*}{2} & 1 & $\begin{array}{l}\text { Write a formula in one } \\
\text { variable to find a } \\
\text { solution }\end{array}$ \\
\hline & & o & $\begin{array}{c}\text { No response or } \\
\text { mathematical sentence } \\
\text { used is incorrect }\end{array}$ \\
\hline & & 1 & $\begin{array}{l}\text { Pursue planning to find } \\
\text { other solutions }\end{array}$ \\
\hline & & o & $\begin{array}{c}\text { No response or } \\
\text { planning was made } \\
\text { incorrectly }\end{array}$ \\
\hline \multirow[t]{6}{*}{$\begin{array}{l}\text { Performing } \\
\text { Plan }\end{array}$} & \multirow{6}{*}{3} & 1 & $\begin{array}{l}\text { The first solution is } \\
\text { obtained from proper } \\
\text { planning (R1) }\end{array}$ \\
\hline & & o & $\begin{array}{c}\text { No response or } \\
\text { implementation of } \\
\text { inaccurate plans }\end{array}$ \\
\hline & & 1 & $\begin{array}{l}\text { Other solutions are } \\
\text { obtained by proceeding } \\
\text { with the proper } \\
\text { implementation of the } \\
\text { plan (R2) }\end{array}$ \\
\hline & & o & $\begin{array}{l}\text { No other solutions are } \\
\text { made or shown }\end{array}$ \\
\hline & & 1 & $\begin{array}{l}\text { L1 and L2 are obtained } \\
\text { through the } \\
\text { implementation of a } \\
\text { clear plan }\end{array}$ \\
\hline & & o & $\begin{array}{l}\text { No response or L1 and } \\
\text { L2 were obtained } \\
\text { without clear planning } \\
\text { of R1 and R2 }\end{array}$ \\
\hline \multirow[t]{2}{*}{$\begin{array}{l}\text { Looking } \\
\text { Back }\end{array}$} & \multirow[t]{2}{*}{1} & 1 & $\begin{array}{l}\text { Check the accuracy of } \\
\text { the solution by } \\
\text { replacing the solution } \\
\text { obtained into the } \\
\text { formula written in } \mathrm{F}_{3}\end{array}$ \\
\hline & & o & No reviews were made \\
\hline
\end{tabular}

Every question in the test is awarded based on the four processes mentioned earlier. Scores are given based on the scoring rubric included in Table 2.

\section{RESULT AND FINDINGS}

Using the rubric in Table 2, the full score for each problem is 9. Table 3 is the descriptive statistics which shows the minimum score, maximum score, mean score and standard deviation of each problem, while Table 4 shows the percentage of each subscore.

Table 3. Descriptive Statistics of Each Problem (N=56)

\begin{tabular}{ccccc}
\hline Problem & Minimum & Maximum & Mean & $\begin{array}{c}\text { Standard } \\
\text { Deviation }\end{array}$ \\
\hline $\mathbf{1}$ & 1 & 8 & 4.04 & 2.335 \\
$\mathbf{2}$ & 0 & 7 & 1.30 & 1.159 \\
$\mathbf{3}$ & 0 & 8 & 2.02 & 1.408 \\
$\mathbf{4}$ & o & 9 & 6.86 & 2.377 \\
\hline
\end{tabular}

From Table 3, it is found that Problem 4 is the only problem that is successfully answered by students with full scores. The majority of students obtained a score of 7-9 for this problem and the mean became 6.86 . The mean score shows that Problem 3 and Problem 2 are the most difficult problems as the majority of students only get a score of $0-3$ for these problems. Problem 1 is moderate, although not many students scored between 7-9, 40\% of them managed to score between 4-6, making the mean score 4.04 .

Table 4. Percentage of Sub-score for Each Problem

\begin{tabular}{|c|c|c|c|c|c|c|}
\hline & Problem & & P1 & P2 & P3 & $\mathbf{P 4}_{4}$ \\
\hline \multirow{13}{*}{$\begin{array}{l}\text { Sub- } \\
\text { scores }\end{array}$} & \multirow{4}{*}{$\begin{array}{l}\text { Understanding } \\
\text { the Problem }\end{array}$} & 3 & 58 & 0 & 8 & 70 \\
\hline & & 2 & 34 & 26 & 48 & 24 \\
\hline & & $\mathbf{1}$ & 8 & 62 & 36 & 4 \\
\hline & & $\mathbf{0}$ & 0 & 12 & 8 & 2 \\
\hline & \multirow{3}{*}{$\begin{array}{l}\text { Planning } \\
\text { Strategies }\end{array}$} & 2 & 16 & 4 & 2 & 72 \\
\hline & & $\mathbf{1}$ & 4 & 0 & 30 & 20 \\
\hline & & $\mathbf{o}$ & 80 & 96 & 68 & 8 \\
\hline & \multirow{4}{*}{$\begin{array}{l}\text { Performing the } \\
\text { Plan }\end{array}$} & 3 & 0 & 0 & 2 & 54 \\
\hline & & 2 & $\mathrm{O}$ & 4 & 2 & 20 \\
\hline & & $\mathbf{1}$ & 40 & o & O & 0 \\
\hline & & $\mathbf{0}$ & 60 & 96 & 96 & 26 \\
\hline & \multirow[t]{2}{*}{ Looking Back } & $\mathbf{1}$ & 20 & 2 & 2 & 46 \\
\hline & & о & 80 & 98 & 98 & 54 \\
\hline
\end{tabular}

From Table 4, it is found that $70 \%$ of the students can understand the problem, $72 \%$ can plan the solution strategy well and 54\% can achieve the correct solution for Problem 4. 
However, only $46 \%$ of students showed a review step for this problem. As for Problem 2 and Problem 3, the majority of students could not understand the problem well, so they failed to find a solution. On the other hand, Problem 1 seems to be easy for students to understand, but it is difficult to find a solution. Out of $58 \%$ of students who understood the overall situation of this Problem 1, none managed to find a proper solution.

As mentioned earlier, a four-phase problem-solving process, which consists of i) understanding the problem, ii) planning strategies, iii) performing the plan, and iv) looking back, was adapted for the study. This section is to look for errors students made in each phase that led to difficulties in solving non-routine problems. The discussion below describes students' calculation process and their responses to the difficulties they faced while solving the problems.

\section{A. Understanding the Problem}

Questions need to be understood before they can be solved (Montague \& Bos, 1986; Polya, 1957; Schoenfeld, 1992b). Therefore, understanding the problem is an important aspect of problem-solving. However, many students found difficulty to do the first phase of the problem-solving process; which was to understand the problem, because non-routine problems are usually lengthy and a lot of information is involved, students are often confused about the purpose of the problem. The following are students' responses to what make them failed to complete the task:

tersebut? Berikan penjelasan terpernnc1.

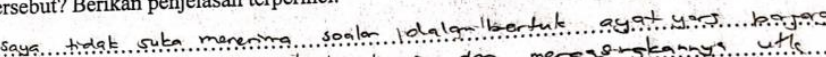

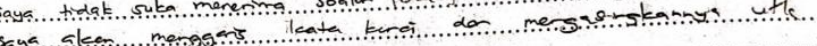

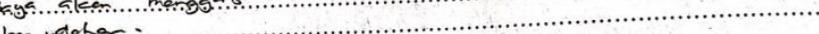

"I don't like questions in form of long sentences, I must underline keywords and isolate them to make it easier to understand."

They are confused as they were unable to understand the information at hand ultimately do not know what to do with all the information. Among the reflections written by students are as follow:

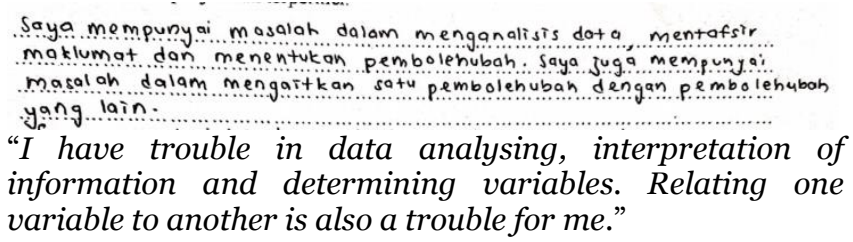

All these weaknesses may lead to more mistakes in the next phase of problem-solving processes. One of the difficulties encountered in this phase is the misinterpretation of the information provided. This misunderstanding leads to uncertainty about what to do with the problem. Some students are unable to relate the problem to the concepts they have learned. For example, Problem 2 is a number puzzle question, it is rarely discussed in class. Students are not familiar with this form of question so there are students who want to relate to mathematical concept such as Fibonacci number even though it is indeed not related to it. Students stated in their reflection that they had never solved such a problem and did not understand the question. Here are some of the students' responses.

Soalan yang dibenkan amat sukar Saya belum ... pernah menue lesaikan ... soalan .... berbentuk seperti ini.

"The questions given are very difficult. I have never solved a question like this.”

Saya sudah belajar di tingleatan 3 raito nomber fiboncei. Saya lupa den berdasarkon sualan juga atan suear difahani

"I have studied Fibonacci number in Form 3. I have forgotten about it, and the question is also difficult to understand"

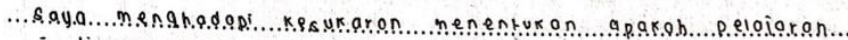

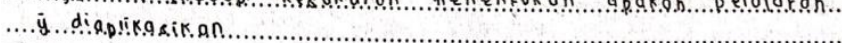

"I have difficulty determining which lessons should be applied."

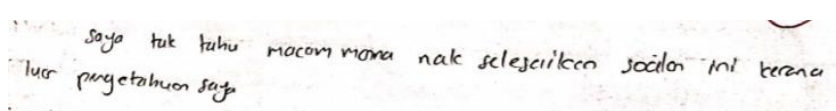

"I do not know how to solve this question because it is beyond my knowledge."

In solving Problem 3, students misinterpreted the information 'passing score for the test is 40\%'. They easily assume $40 \%$ equals 40 marks without considering the full marks of the test. Many students also considered the full marks for the test is 100 . These misinterpretations led them to inaccurate solutions. Figure 1 below shows an example of student responses. 


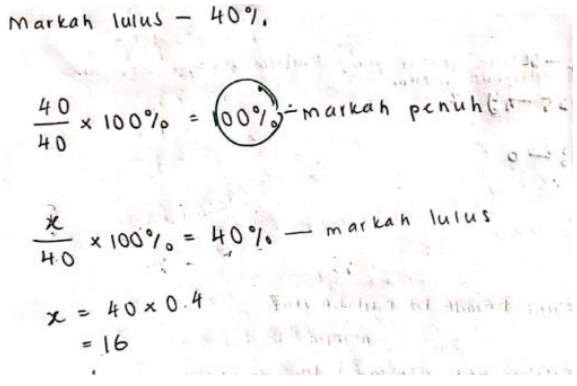

Figure 1. Misinterpretations of Problem 3

Four questions used in this study are non-routine problems that are rarely discussed in the classroom. Although these questions do not require complicated calculations, students need to understand every bit of information provided to understand the problem. They do require information management skills such as manipulating information, making connections between each information, stating mathematical sentences, and deciding which operations or formulas to be used. However, manipulating information and formulating situations mathematically are found to be a major subset of information management skills that influence difficulty in problem-solving (Tarzimah \& Thamby Subahan, 2010).

In this study, students have difficulty in making connections between each piece of information, although they can identify important information well. For example in Problem 1, students can state and represent each of banknotes of RM1, RM5 and RM2O as $x, y$ and $z$, respectively. However, they could not connect the variables $x, y$ and $z$ properly due to the difficulty of understanding the given questions. Students misunderstood certain mathematical terminologies such as "more than" and "less than", resulting in the connection between each variable cannot be formed correctly. In other words, they are unable to decipher problem-situation well. Figure 2 shows that students are able to make representations through symbols but are unable to write equations correctly.

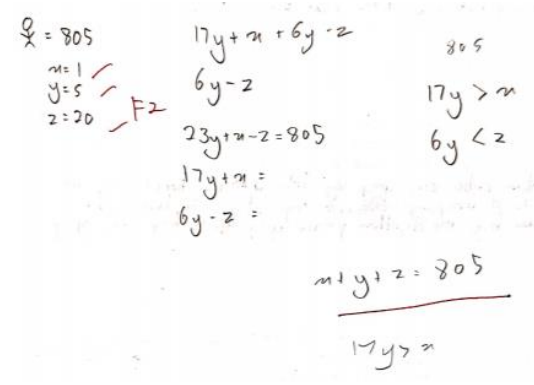

Figure 2. Response (I) on Problem 1
Transforming a problem into a mathematical sentence is a difficult thing to do (Powell \& Fuchs, 2014). From the reflections written by the students in this study, they face difficulties when trying to connect the information given in the question. They fail to construct appropriate mathematical representations and end up leaving the problems without solving them.

Tak boleh buat ayat matemetit se cara lengkap: noka guna kaedah tamber to ial sahga

"Cannot make a complete mathematical sentence, only using addition and subtraction methods."

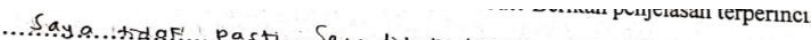

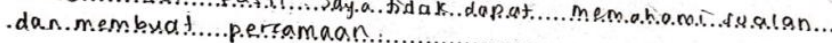
"I'm not sure. I can't understand the question and make equations."

Saym tak tahu nak gura formula apa

"I do not know which formula to be used."

The confusion that students face is due to difficulties in understanding the mathematical terms used or making incorrect connections between each information (Tarzimah \& Thamby Subahan, 2010). As a result, it takes longer to understand the question, resulting in more time to solve the problem. Therefore, the timeframe given may not be enough for students to solve all the problems. Although it takes a long time to solve a problem, they are unsure of the answer and every solution step taken. This statement is evidenced by the reflections written by the students.

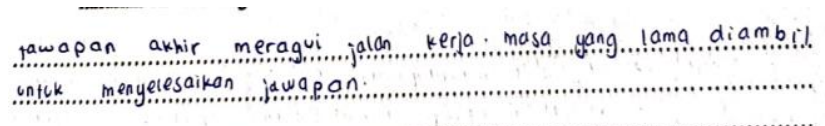

"The final answer doubts the calculations. It took a long time to solve the problem"

Tarzimah \& Thamby Subahan (2010) adds that the process of understanding problems requires reading skills and visualspatial skills to understand the goals. However, lacking these skills, the students make it difficult to identify the goals and objectives mentioned in the problem. As a result, they cannot even decide on how to resolve the issue on planning and implementing a problem-solving strategy. 


\section{B. Planning Strategies}

Understanding the problem alone does not guarantee that a student can solve the problem. Often, when a student understands a problem, one still cannot determine the steps to solve the problem. For instance, Problem 1, out of $70 \%$ who understood the problem, only $20 \%$ managed to solve the problem successfully. This means, understanding the problem does not guarantee a person to solve the problem. The students' responses to Problem 1 in Figure 3 below indicate that they understood the problems but cannot plan the appropriate solution strategy and thus, they were unable to solve the problem. Compared to Figure 2, the student in Figure 3 can write equations in three variables correctly, but cannot relate the relationship between $x, y$ and $z$ to form equations in one variable. Although all the information has been well identified and systematically listed, the student in Figure 3 can only connect $x$ and $y$ but cannot connect $x$ and $z$. Eventually he could only write the equation as $x+5(x+17)+$ $20 z=805$ instead of $x+5(x+17)+20(x+23)=805$ and could not find a solution.

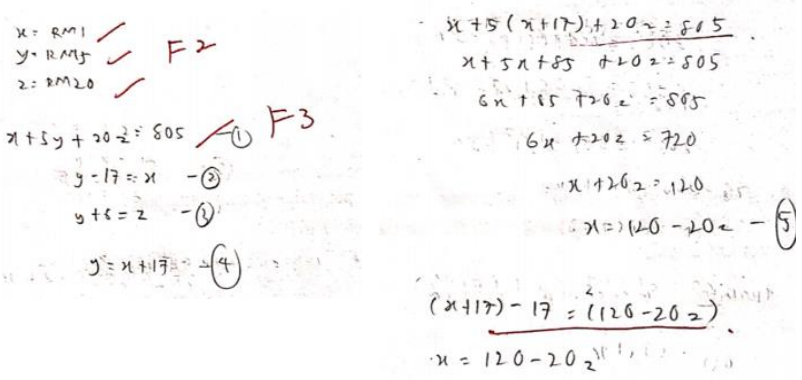

Figure 3. Response (ii) on Problem 1

As mentioned earlier, Problem 2 is a puzzle type problem that is rarely discussed in class. Therefore, they do not have sufficient exposure to solve such problems. Because of that, they do not know what to, do to solve the problem. Most of the students simply left the answer space blank unattended. Others simply fill in the box with any number they thought appropriate without considering the conditions given in the question.

As for Problem 3, students do not know how to determine the number of correct answers that was needed to be given by Melissa. Some of them simply divided 64 by 4 , without considering the deducted marks from the wrong answer (See Figure 4). This difficulty may be due to lacking algebraic skills and information management skills. The relationship between inaccurate information and facts or the relationship between inaccurate facts and formulas can cause students to misinterpret information in reaching a solution. Also, this lack of skills can lead to inappropriate planning which later creates an error and confusion in the problem-solving process. Many types of mathematical skills difficulties may arise from the inability to connect and transfer mathematical, conceptual aspects to the knowledge and incomplete mastery of numbers.

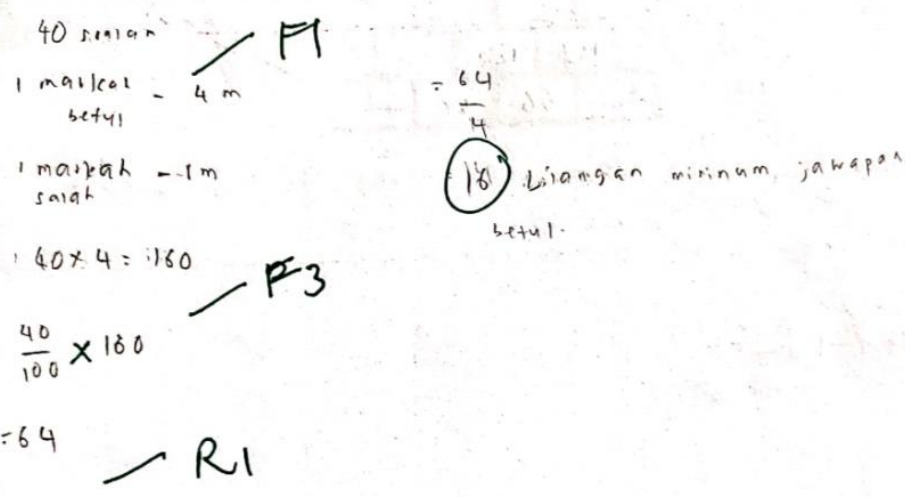

Figure 4. Response on Problem 3

Even though students have understood the problem and the conditions given in the problem, students still cannot show strategic planning to solve the problem. They are more likely to find answers by guessing and checking for problems 1 and Problem 4. They obtained the correct answer without showing appropriate justification. Examples of student responses using trial and error method for Problem 1 and Problem 4 are shown in the figure below.
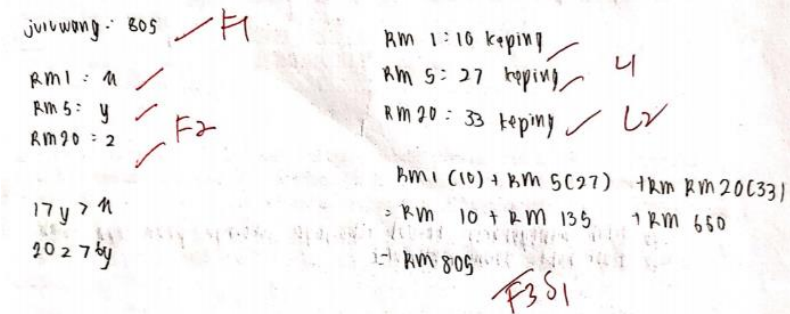

Figure 5. Trial and Error used on Problem 1 


\section{7}

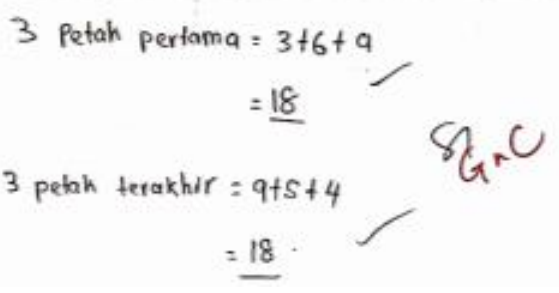

Figure 6. Trial and Error used on Problem 4

Among the reflections written by students are as follow:

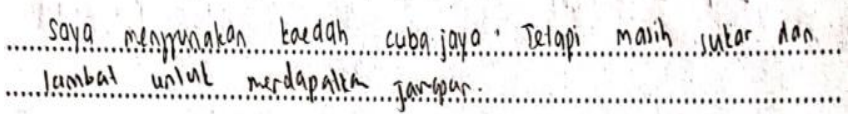

"I use the trial and error method, but it is still difficult and takes time to get the answer".

$$
\begin{aligned}
& \text { Sayo tldak dapal menentukan cara apa yang diperluka } \\
& \text { digunakan untuk menyelesaikan mosalah itu Saya akan. } \\
& \text {.....ba joyo untuk mendapatkan ja wapan dan cuba } \\
& \text {...memikirkan jolan kerja terbajk bagi soalan tersebuy } \\
& \text { melalui jawapan cuba jaya sayo }
\end{aligned}
$$

"I cannot determine which method should be used to solve this problem. I will use trial and error to get an answer and try to think of the best way to work on the calculations through the answers I got."

These reflections clearly show that students were unable to plan solution strategies even though they understand the problem. This may be due to lacking exposure to non-routine problems in mathematics learning in the classroom. Students do not have enough practices to solve such problems.

\section{Performing the Plan}

During the third phase, students have to work out strategies to solve the problem and get the answer. In this process, students must be able to make the right decisions and decide what to do. They need to have skills in managing information and managing problem-solving strategies. Since the problem-solving process is hierarchical, obstacles in the first phase will cause failure in the next phase. To execute the strategy, arithmetic skills and numerical skills are important. With these skills, students can apply correct concepts and facts and can make accurate calculations. However, most students are not familiar in all of these skills. Figure 7 shows the students' response to Problem 1. Although at first, he could not relate the relationship between $x$ and $z$, however with constant effort, he finally managed to get the correct value of $y$. However, he did not proceed with the plan to find the values of the other variables, namely $x$ and $z$. This negligence can be avoided if students review the requirements of the question.
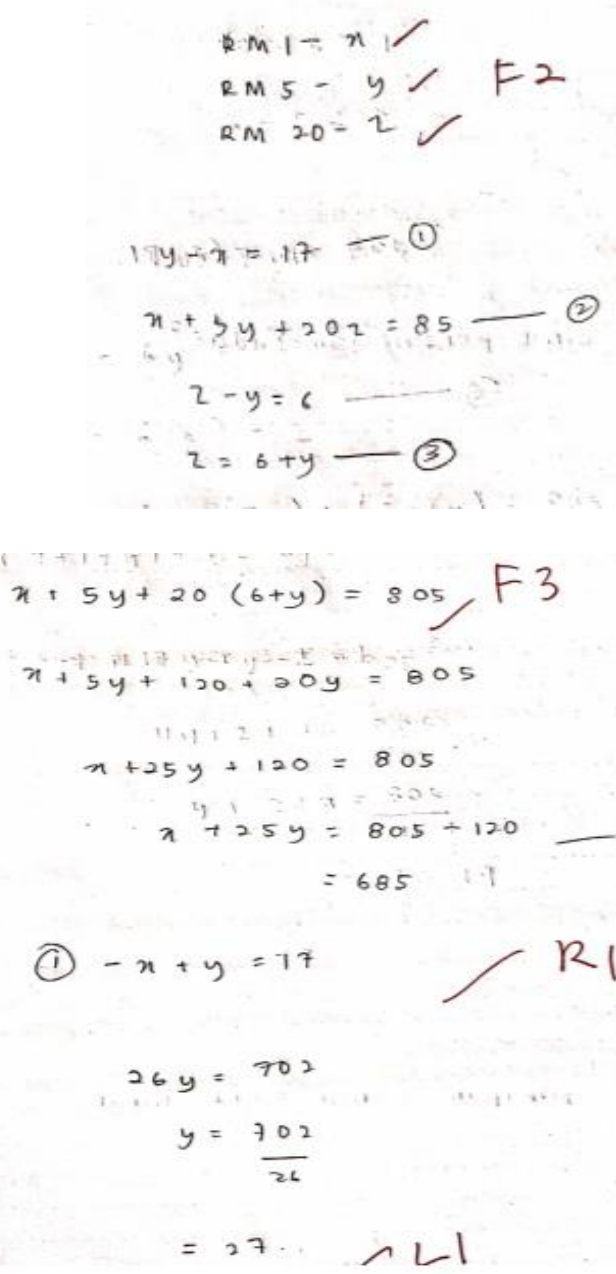

Figure 7. Response (iii) on Problem 1

Problem 2 is a puzzle type problem adapted from the problem found in Arcavi (2008). For this problem, most students even those who are familiar with algebra techniques, approach this problem numerically. Some chose two numbers and placed them in the first row, then added them to get the solution. It is quite rare that a first guess will lead to a correct solution, namely, to fill all the cells such that the last sum becomes 450 . Others chose to solve the problem by decomposing 450 to 225 and 225 and proceeding with the countdown. However, this attempt made them failed to produce the correct answer (See Figure 8). 


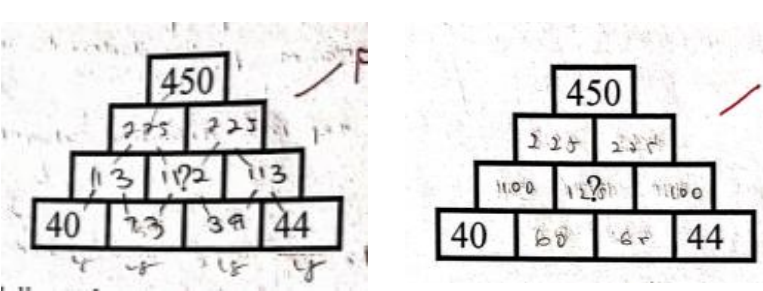

Figure 8. Responses on Problem 2

For Problem 4, a lot of negligence occurred while students making calculations. As shown in Figure 9, this student was careless when copying the number 14 as 4 , as a result, the calculation became inaccurate.

$$
\begin{gathered}
7+x+y+z=30 \\
7+(15-y)+y+(14-y)=30 \\
7+15-y+y+14-y=30 \\
y+y-y+7+15-4)=30 \\
y+\frac{26}{y}=30 \\
=30-26 \\
=4
\end{gathered}
$$

Figure 9. Response on Problem 4

Students made many mistakes while performing operations on algebra to change the subject of the formula. For example, instead of $3+x+y=18$, they wrote $x=y+15$. Besides, the operations on algebra were always wrongly used involving negative coefficients, as shown in Figure 10 and Figure 11.

$$
\begin{aligned}
& 3+x+y+z=30 \\
& 3+x+y=y+z+4=18 / R 1 \\
& 3+x+y+z=30-(1) \\
& 3+x+y=18 \\
& y+z+4=18
\end{aligned}
$$

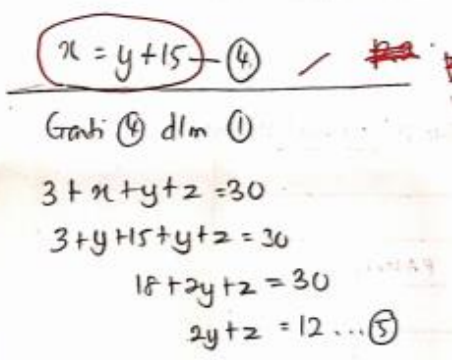

Figure 10. Algebraic error (i) on Problem 4

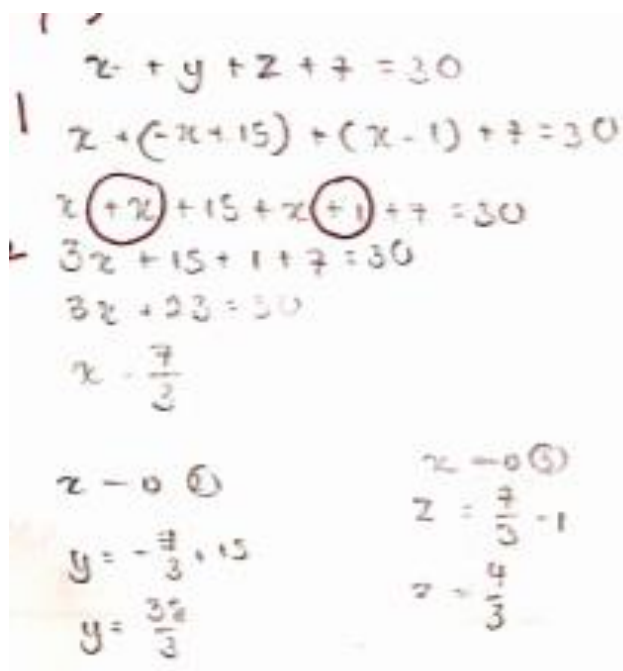

Figure 11. Algebraic error (ii) on Problem 4

These small mistakes, if left unchecked, will lead to bigger problems when learning more complex algebra in the future.

\section{Looking Back}

Students often neglected the fourth phase in the problemsolving process which is looking back. They felt this phase is unnecessary since the first three phases are quite challenging for them. Some students stated that they were already bored when they could reach for an answer because it took time to solve it. This time-consuming process makes them less interested in seeing the same problem again. Some of them 
feel drowsy when facing the problem that was too difficult as the reflection was written below.

\section{it was too hard, im sleppy}

At the same time, they were running out of time to move on to the next question, which also required a long thinking process. Therefore, they cannot concentrate on a task for a longer time. For them, if they have been successful through the first three phases, it is considered successful to them. However, this opinion is misled as misunderstandings of the problem may occurred or accidental errors have been made during the problem-solving process. Negligence while making calculations can be corrected when students review all the requirements of the question and evaluate each solution step that has been taken.

\section{DISCUSSIONS}

Geary (2004) argues that conceptual understandings and procedural knowledge influence achievement in problemsolving. From the above results, it is found that students face difficulties at each phase of the problem-solving process. The phases of the problem-solving process are interrupted if students are lacking mathematical skills such as facts, concepts, and arithmetic skills.

Previous researchers (Abdurrahman et. al., 2020; Ling et. al., 2019; Özsoy et. al., 2015; Ying et al., 2020) have proven that mastery of language skills is very important because students need to have high-level reading skills to form mathematical sentences until they reach a solution. This case occurs primarily to solve problems involving algebra that require more complex reasoning to deal with unknown numbers. A study conducted by Ying et al. (2020) found that the dominant difficulty faced by primary school students in problem-solving is text difficulties. Students have difficulty constructing mathematical sentences when involving words such as 'more than' or 'less than'. This difficulty seems to occur not only in primary school students, but secondary school students in this study are also facing the same difficulties. This indicates that these difficulties need to be overcomed from an early stage so that students can learn mathematics better at the next level.
Lacking language skills such as understanding mathematical terminologies can hinder understanding of problem objectives and may affect the ability to solve problems. In helping to interpret and manipulate information effectively in working memory, language and visual-spatial skills are essential (Geary, 2004). In addition to students lacking in conceptual understanding, students are also having difficulty in systematically demonstrating work procedures and ensuring the accuracy of their work procedures. This is a key skill in arithmetic skills that resulting in students' difficulty in solving problems. Heong (2005) states that weaknesses in conceptual understanding and lack of strategic knowledge have led to difficulties in solving problems. Therefore, there may be interactions between these skills.

The main cognitive ability to learn that may cause students to encounter difficulties in solving problems is the ability to access existing knowledge and to recall facts related to making connections in their thinking. This ability indirectly affects the efficiency of critical mathematics skills in problemsolving ability. Students may have trouble retrieving the facts involved and recalling past learning experiences. These deficiencies can lead to difficulties in information management skills. As a result, students are unable to bring meaning to the problem and thus have difficulty in finding the right concepts, formulas, facts, and procedures in solving the problem.

From the analysis of this study, we can say that the dominant difficulty faced by high-achieving students are reading skills and information management skills. This finding is in line with opinion Jupri \& Drijvers (2016) which says that the main difficulty faced by students while solving problems involving algebra is to convert the problem into a mathematical sentence. In other words, they have difficulty in formulating situation mathematically. This finding is also in line with the report that says that the score of Malaysian students in formulating is lower than the score of employing and interpreting at PISA 2012 (OECD, 2014).

Many students believe that the difficulties they face in preventing mathematical achievement come from difficult, tedious mathematics problems, which require a lot of knowledge, work procedures, and time. However, the real obstacle is not the mathematical problem but rather the 
deficiency of all the mathematical skills in the student. Mathematical problems will no longer be a hindrance if students can master the skills required. Therefore, one way to help students realise their weaknesses and to try to overcome them is to diagnose the skills involved. The findings could help in the planning of an approach to teaching this group of students more effectively. Teaching mathematics concepts and skills using a contextual approach with logic can be adapted for this group of students. However, further research is essential.

To implement more effective and explicit learning strategies, teachers need to understand students' difficulties and their learning processes for the meaningful learning of their students (Meese, 2001). The ability to focus well, to make meaningful perceptions, and to think logically and to use memory effectively are as important in learning skills and problem-solving. Therefore, if teachers understand students' difficulties, they can adapt their teaching approach to create meaningful learning based on students' intellectual needs as these skills can be learned and practised.

\section{CONCLUSION}

The main conclusions of this study indicate that lacking cognitive skills and incompetence in acquiring many mathematical skills are the reasons why students face difficulties in solving non -routine problems. Difficulties in understanding and managing information are considered to be the most dominant difficulties; without information transfer skills, they are unable to understand and make effective connections with the information in the problem, even if students acquire other mathematical skills. The ability to remember, memorise, and evaluate is a cognitive ability in learning that influences problem-solving competence.
Difficulties in students 'math skills are a challenge that must be overcome. Lacking language skills and information management skills will interfere with the efficiency of the problem-solving process. The efficiency of each phase in problem solving depends on the ability to remember, especially problems involving facts. In this study, students tend to remember what they had learned without understanding the actual concept. Most of students try to memorise and apply mathematical rules and definitions without fully understanding the underlying concepts. Students find it difficult to make meaningful connections with problems and influence the efficiency of the next phase of solution. Therefore, the ability to manage information is a key factor in determining the smoothness of the problemsolving phase. Therefore, it is recommended that educators review the concept and its application in daily life to cultivate students' ability in solving non -routine problems. It is highly encouraged that educators place more emphasis and involve students with non -routine problems in their classrooms. If this is not done, students may not have sufficient skills and in the long run may not survive in their math problem-solving experience. Reflected to this study, we tried to design an appropriate teaching approach to facilitate our students to solve non -routine problems involving algebra as an extension to this study.

\section{ACKNOWLEDGEMENT}

We are grateful for the financial support from the Federal Training Gift (HLP), Ministry of Education Malaysia, and Universiti Teknologi Malaysia, for making this study possible.

ometric_thinking_in_learning_3D_geometry_among_hi gh_achievers>.

Abdul Halim, A, Nur Liyana, ZA \& Marlina, A 2015, 'Analysis of Students' Errors in Solving Higher Order Thinking Skills (HOTS) Problems for the Topic of Fraction', Asian Social

Science, vol. 11, no. 21, pp. 133-142,
Abd Wahab, R, Abdullah, AH, Abu, MS, Mokhtar, M \& Atan, NA 2016, 'A case study on visual spatial skills and level of geometric thinking in learning 3D geometry among high achievers', Man in India, vol. 96, no. 1-2, pp. 489-499, $<$ https://www.researchgate.net/publication/298640083 A_case_study_on_visual_spatial_skills_and_level_of_ge 
<https://doi.org/10.5539/ass.v11n21p133>.

Abdurrahman, MS, Abdullah, AH \& Osman, S 2020, 'Developing mathematical thinking among polytechnic students in linear algebra through peer tutoring strategy', Journal of Advanced Research in Dynamical and Control Systems, vol. 12, no. 3, pp. 423-434, <https://doi.org/10.5 373/JARDCS/V12I3/20201210>.

Arcavi, A 2008, Algebra: Purpose and Empowerment. In CE, Greenes \& R, Rubenstein (Eds.), Algebra and Algebraic Thinking in School Mathematics (Seventieth, pp. 37-50), National Council of Teachers of Mathematics.

Arslan, C \& Altun, M 2007, 'Learning to solve non-routine mathematical problems', Elementary Education Online, vol. 6, no. 1, pp. 50-61, <https://core.ac.uk/download /pdf/230033077.pdf $>$.

Arslan, C \& Yazgan, Y 2015, 'Common and flexible use of mathematical non routine problem solving strategies', American Journal of Educational Research, vol. 3, no. 12, pp. 1519-1523, <https://doi.org/10.12691/education-3-126>.

Brunning, RH, Schraw, GJ \& Ronning, RR 1999, Cognitive Psychology and Instruction, 3rd edn, Prentice-Hall Inc.

Curriculum Development Division, M 2015, Form 1 Mathematics Curriculum and Assessment Standard Document, Ministry of Education, Malaysia, $<$ https://gurubesar.my/wp-content/uploads/2018/11/o2DSKP-KSSM-Tingkatan-1-Matematik.pdf>.

Curriculum Development Division, M 2016, Year 1 Mathematics Textbook (Vol. 1). Ministry of Education, Malaysia, < <https://drive.google.com/file/d/1phXBnXfTvi-S55-qRUVfseEV-k646ly/view>.

Garderen, DV 2006, 'Spatial visualization, visual imaginary and mathematical problem solving of students with varying abilities', Journal of Learning Disabilities, vol. 39, no. 6, pp. 496-506,

<https://doi.org/https://www.researchgate.net/deref/htt p\%3A\%2F\%2Fdx.doi.org\%2F10.1177/2Fo0222194060390 060201>.

Geary, DC 2004, 'Mathematical and learning disabilities', Journal of Learning Disabilities, vol. 37, no. 1, pp. 4-15, <https://doi.org/https://doi.org/10.1177/2Foo222194040 370010201>.

Hegarty, M, Mayer, RE \& Monk, CA 1995, 'Comprehension of arithmetic word-problems - a comparison of successful and unsuccessful problem solvers', J. Educ. Psychol., vol. 87, no. 1, pp. 18-32.

Heong, TL 2005, Problem Solving Abilities and Strategies in
Solving Multistep Mathematical Problems among Form 2 Students, Universiti Malaya.

Jacinta, J, Abdul Halim, A, Mohd Salleh, A, Mahani, M \& Noor Azean, A 2017, 'Difficulties in reasoning among high achievers when doing problem solving in mathematics', Man in India, vol. 97, no. 12, pp. 61-70, <https://www.researchgate.net/profile/Abdul_Abdullah1 o/publication/318635080_Difficulties_in_reasoning_am ong_high_achievers_when_doing_problem_solving_in_ mathematics/links/5972e64da6fdcc8348826473/Difficult ies-in-reasoning-among-high-achievers-when-doing-p $>$.

Jupri, A \& Drijvers, P 2016, 'Student difficulties in mathematizing word problems in Algebra', Eurasia Journal of Mathematics, Science and Technology Education, vol. 12, no. 9, pp. 2481-2502, <https://doi.org/10.12973/eur asia.2016.1299a $>$.

Lester, F \& Cai, J 2015, 'Can mathematical problem solving be taught? Preliminary answers from thirty years of research', in B. Aires (Ed.), Posing and Solving Mathematical Problems: Advance and New Perspectives, (Eds, Issue January), Springer, <https://doi.org/10.1007/978-3-319-28023-3>.

Lester, FK 2013, "Thoughts about research on mathematical problem- solving let us know how access to this document benefits you', The Mathematics Enthousiasm, vol. 10, n o. 1, p p. 245-278, <https://scholarworks.umt.ed $\mathrm{u} /$ cgi/viewcontent.cgi? article $=1267 \&$ context $=$ tme $>$.

Ling, CY, Osman, S, Daud, MF \& Hussin, WNW 2019. 'Application of vee diagram as a problem-solving strategy in developing students' conceptual and procedural knowledge', International Journal of Innovative Technology and Exploring Engineering, vol. 8, no. 10, pp. 2796-2800, <https://doi.org/10.35940/ijitee.J9591.0881019>.

Mabilangan, RA, Limjap, AA \& Belecina, RR 2011, 'Problem solving strategies of high school students on non-routine problems', Alipato: A Journal of Basic Education, vol. 5, pp. $23-46$,

$<$ https://www.google.co.id/url?sa=t\&rct=j\&q=\&esrc=s\&s ource $=$ web\&cd $=7 \& c a d=$ rja\&uact $=8 \& v e d=$ oahUKEwjbgbT 33cDRAhXDRo8KHRNOCVkQFgg1MAY\&url=http://jour nals.upd.edu.ph/index.php/ali/article/download/2759/25 8o\&usg=AFQjCNEZYXA5YDiNUDoJ6lajFqlQeFPv5g\&sig 2=nBexCQ95F5pxi>

Meese, RL 2001, Teaching learners with mild disabilities integrating research and practice, 2nd edn, Singapore: Wadworth Thomson Learning.

Ministry of Education, M 2013, Malaysia Education 
Development Plan $2013 \quad$ - 2025, <https://doi.org/10.1016/j.tate.2010.08.007>.

Ministry of Education, M 2016, Gred Markah Peperiksaan UPSR, PT3 dan SPM, pp. 1-3, <https://sapsnkra.moe.gov.my/dokumen/GRED.pdf>.

Montague, M \& Bos, CS 1986, 'The effect of cognitive strategy training on verbal math problem solving performance of learning disabled adolescents', Journal of Learning Disabilities, vol. 19, no. 1, pp. 26-33, <https://doi.org/10.1177/002221948601900107>.

OECD 2014, PISA 2012 Results in Focus, Programme for International Student Assessment, pp. 1-44, <https://doi.org/10.1787/9789264208070-en>.

Özsoy, G, Kuruyer, HG \& Çakiroğlu, A 2015, 'Evaluation of students' mathematical problem solving skills in relation to their reading levels', International Electronic Journal of Elementary Education, vol. 8, no. 1, pp. 581-6oo.

Polya, G 1957, 'How to solve it: a new aspect of mathematical method', in The Mathematical Gazette (2nd edn, vol. 30), Doubleday Anchor Books, <https://doi.org/10.2307/3609122>.

Polya, G 1981, 'Mathematics discovery: an understanding, learning, and teaching problem solving', in New York: John Willey \& Son.

Polya, G 2004, How to solve it: a new aspect of mathematical method, Princeton University Press.

Powell, SR \& Fuchs, LS 2014, 'Does early algebraic reasoning differ as a function of students' difficulty with calculations versus word problems?', Learning Disabilities Research and Practice, vol. 29, no. 3, pp. 106-116, <https://doi.org/10.1111/ldrp.12037>.

Roy, G 2014, Developing prospective teachers' understanding of addition and subtraction with whole numbers, issues in the Undergraduate Mathematics Preparation of School Teachers,

2(March), <https://files.eric.ed.gov/fulltext/EJ1043049.pdf>.

Schoenfeld, AH 1992a, Learning to think mathematically: sense-makingin mathematics, Handbook for Research on Mathematics Teaching and Learning, pp. 334-370.

Schoenfeld, AH 1992b, Learning to think mathematically: problem solving, metacognition, and sense making in mathematics, Handbook on Research on Mathematics Teaching and Learning: A Project of the National Council of Teachers of Mathematics, vol. 196, no. 2, pp. 355-358, <https://doi.org/10.1177/002205741619600202>.

Tarzimah, T \& Thamby Subahan, MM 2010, 'Students' difficulties in mathematics problem-solving: What do they say?', Procedia - Social and Behavioral Sciences, vol. 8, pp. 142-151, <https://doi.org/10.1016/j.sbspro.2010.12.020>.

Xin, Z, Lin, C, Zhang, L \& Yan, R 2007, 'The performance of chinese primary school students on realistic arithmetic word problems', Educational Psychology in Practice, vol. 23, n o. 2, p p . 145-159, <https://doi.org/10.108o/o26 $67360701320853>$.

Yazgan, Y, Faculty, E \& Arslan, C 2012, 'Common and flexible use of mathematical non routine problem solving strategies', 12th International Congress on Mathematical Education, vol. $3, \quad$ no. $12, \quad$ pp. 3044-3052, <https://doi.org/10.12691/education-3-12-6>.

Ying, CL, Osman, S, Kurniati, D, Masykuri, ES, Kumar, JA \& Hanri, C 2020, 'Difficulties that students face when learning algebraic problem-solving', Universal Journal of Educational Research, vol. 8, no. 11, pp. 5405-5413, <https://doi.org/10.13189/ujer.2020.081143>. 
APPENDIX 1: PROBLEMS USED IN THIS STUDY

\begin{tabular}{|c|l|l|}
\hline Number & \multicolumn{3}{|c|}{ Problem } \\
\hline 1 & $\begin{array}{l}\text { A cashier has amount of money of RM805. He has only RM1, RM5 and RM20 banknotes. He } \\
\text { has 17 pieces of RM5 banknotes more than RM1 banknotes. He has 6 pieces of RM5 banknotes } \\
\text { less than RM20 banknotes. How many pieces of each banknotes does he have? Show each } \\
\text { solution step clearly. }\end{array}$ \\
\hline 2 & $\begin{array}{l}\text { Fill in the white cell in figure 1 in such a way that each number is the sum of the two numbers } \\
\text { located immediately below it. Show each solution step clearly. }\end{array}$ \\
\hline 3 & $\begin{array}{l}\text { There are 40 questions in a Math test. For each correct answer, } 4 \text { marks are given and for each } \\
\text { incorrect answer } 1 \text { mark will be deducted. If the passing score for the test is } 40 \%, \text { what is the } \\
\text { minimum number of correct answers that Emelda needs to give to ensure that she passes the } \\
\text { test. Show each solution step clearly. }\end{array}$ \\
\hline 4 & $\begin{array}{l}\text { Rita wants to create a 5digit access code for her door. She has already written two numbers as } \\
\text { shown in the diagram below. She wants the sum of all the numbers equal to 30 and the sum of } \\
\text { the numbers in the first three squares equals to the sum of the numbers in the last three squares } \\
\text { that is 18. What is Rita's access code actually? Show each solution step clearly. }\end{array}$ \\
\hline 3 & 450 \\
\hline
\end{tabular}

